\title{
Dışa Dönük Kişilik Özelliğinin Grup Uyumu Üzerine Etkisi: Hakkâri'deki Özel Güvenlik Personeli Üzerinde Bir Araştırma \\ (Effect of Extroversionist Personality Trait on Group Cohesion: A Study on Private Security Staff in Hakkâri)
}

\author{
Hava YAŞBAY KOBAL (iD) a Savaş ŞİMŞEK (iD) \\ a Hakkâri Üniversitesi, İktisadi ve İdari Bilimler Fakültesi, Hakkâri, Türkiye. havayasbay@hakkari.edu.tr \\ b Hakkâri Emniyet Müdürlügüu, Hakkâri, Türkiye.ssim1971@gmail.com
}

\begin{tabular}{|c|c|}
\hline MAKALE BİLGİSİ & ÖZET \\
\hline $\begin{array}{l}\text { Anahtar Kelimeler: } \\
\text { Dışadönük Kisilik Özelliği }\end{array}$ & $\begin{array}{l}\text { Amaç - Bu çalışma, örgüt çalışanlarında bulunan dışadönük kişilik özelliğinin grup uyumuna etkisinin } \\
\text { olup olmadığının belirlenmesi amacıyla yapılmıştır. }\end{array}$ \\
\hline $\begin{array}{l}\text { Küçük Gruplar } \\
\text { Grup Uyumu } \\
\text { Özel Güvenlik Sektörü }\end{array}$ & $\begin{array}{l}\text { Yöntem - Bu çalışma, özel güvenlik personelinin örgütsel kimlik algılarının örgütsel bağlılık } \\
\text { düzeylerine olan etkisinin test edilmesi amacıyla ilişkisel tarama modeliyle yapılmıştır. Çalışmada alan } \\
\text { olarak belirlenen Hakkâri'de görevli } 351 \text { Özel Güvenlik personeli üzerinde anket tekniği uygulanmıştır. } \\
\text { Dışadönük kişilik özelliğinin belirlenmesi amacıyla John ve Srivastava'nın (1999) kişilik ölçeği, grup } \\
\text { uyumunun ortaya çıkarılması amacıyla da Carron vd.'nin (1985) grup uyumu ölçeği kullanılmıştır. } \\
\text { Verilerin analizinde SPSS } 25 \text { nicel veri analiz programı kullanılmıştır. }\end{array}$ \\
\hline $\begin{array}{l}\text { Revizyon Tarihi } 27 \text { Ocak } 2021 \\
\text { Kabul Tarihi } 10 \text { Mart } 2021\end{array}$ & $\begin{array}{l}\text { Bulgular - Analizler sonucunda özel güvenlik personelinin iş tecrübesi arttıkça dışa dönük kişilik } \\
\text { özelliği düzeyinin azaldığı saptanmıştır. Lise ve üniversite mezunu özel güvenlik personelinin grup } \\
\text { sosyal çekicilik algılarının fazla olduğu anlaşılmaktadır. Özel güvenlik personelinin grup uyumunun } \\
\text { her iki boyutu ile iş tecrübesi değişkeni arasında anlamlı bir farklılık saptanmıştır. Dışa dönük kişilik } \\
\text { özelliğinin grup uyumu üzerinde anlamlı bir etkisi olduğu araştırmanın bir diğer sonucudur. }\end{array}$ \\
\hline Si & $\begin{array}{l}\text { Tartışma - Geçmişe dönük uzun bir süreci olan grup çalışmalarında önemli bir yeri olan grup uyumu } \\
\text { kavramının tam olarak tanımının ortaya konamamış olması onun sadece belirli kavramlarla } \\
\text { ilişkilendirilmesine neden olmuştur. Bu nedenle grup içerisinde yer alan bireyi ve onun kişilik yapısını } \\
\text { ön plana çıaran bu çalışma grup çalışmalarında bireysel özelliklere daha fazla önem verilmesi } \\
\text { gerektiğine dair bakış açısı kazandırabilecektir. }\end{array}$ \\
\hline
\end{tabular}

\begin{tabular}{l} 
ARTICLE INFO \\
\hline Keywords: \\
Extrovert Personality Trait \\
Small Groups \\
Group Cohesion \\
Private Security Sector
\end{tabular}

Received 13 Ekim 2020

Revised 27 January 2021

Accepted 10 March 2021

Article Classification:

Research Article

\section{ABSTRACT}

Purpose - This study was conducted with the aim of establishing whether there is an effect of extroversionist personality trait on group cohesion.

Design/methodology/approach - This study was conducted with a correlational screening model to test the effect of organizational identity perceptions of private security personnel on organizational commitment. Survey technique was applied on 351 Private Security personnel employed in Hakkâri, which was determined as the field in the study. John and Srivastava's (1999) personality questionnaire was used in order to establish the extroverted personality trait, and the group cohesion questionnaire of Carron et al. (1985) was used in order to establish the group cohesion. SPSS 25 quantitative data analysis program was used to analyze the data.

Results - According to the results which were obtained at the end of the study it was established that there is a positive relation between extroverted personality trait and the group coherence. It is understood that the group social attraction perceptions of high school and university graduates are high. A significant difference was found between both dimensions of group compliance of private security personnel and the work experience variable. Another result of the study is that extroverted personality trait has a significant effect on group cohesion.

Discussion - Not revealing of the definition of the concept of group cohesion which has an important place in group studies which have a long retroactive process caused it to be connected only with certain concepts. So, this study which brings the individual in the group and his/her personality to the forefront will be able to bring a point of view of putting emphasis on personality traits in group studies. 


\section{GİRISS}

İnsanoğlunun davranışlarına en fazla etkisi bulunan olgular, savaşlar ve doğal felaketlerdir. Bu tür olgular insanların bir yaşam standardı ve buna bağlı olarak da belirli bir davranış kalıbı geliştirmelerine neden olmaktadır. İşte insan kişiliğinin tespitinde derinlemesine bir analiz yapıldığında yine karşımıza bu tür olguların çıktığını görmekteyiz. Psikoloji alanına bir göz gezdirildiğinde, kişilik üzerine yapılan araştırmalara öncelikle Francis Galton tarafından başlandığını (Dumont, 2010:30) bu çalışmaların daha sonradan Wundt ve öğrencileri tarafından geliştirildiğini öğrenmekteyiz. Psikoloji alanında Wundt ve öğrencilerinin yaptıkları bu çalışmaların Birinci Dünya Savaşının hemen öncesinde askeri amaçlı oldukları tarihselliğini korumaktadır (Shephard, 2015:944). Aslına bakılacak olunursa Birinci Dünya Savaşının psikoloji ve ekonominin birleşimi için bir dönüm noktası olduğundan da bahsedilebilir. Zira Amerika Birleşik Devletleri yönetimi, Birinci Dünya Savaşı sonrası kendi ülkelerine yönelik göçü kontrol altına alabilmek amacıyla yine psikoloji biliminden faydalanarak belirli bir zekâ seviyesinin altında olanların ülkelerine girmelerine engel olmak istemiştir. Bu dönem İngiltere'de de "endüstriyel psikolojinin" temelinin atıldığı yıllara denk gelmektedir (Shephard, 2015:946). Fakat insan unsuru üzerinde yapılan ve ekonomiye eklemlenen bu çalışmalar sonuçta, kalifiye işçiaz ücret dengesizliği ile 1929 yllında başta ABD olmak üzere meydana gelen ekonomik çöküşü meydana getirmiştir (Fiorillo, 2019). II. Dünya savaşı yıllarına gelindiğinde ise psikolojinin yine tek başına askeri amaçlar için kullanıldığını görmekteyiz (Broudy, 2019). Fakat II. Dünya savaşı sonrası meydana gelen ekonomik gelişmeler psikoloji çalışmalarını da hızlandırmış, bu alanda çalışan bilim insanları insan kişiliği ile ilgili daha önceden yapılmayan veya eksik kalan çalışmaları yapmaya başlamışlardır. Bu kapsamda Allport, Odbert, Cattell, Goldberg, McCrae ve Costa'nın kişilik çalışmaları önem arz etmektedir. Özellikle Allport ve Odbert tarafından yapılan kişilik belirleme süreci günümüze kadar geçerliliğini koruyan Cattell'in geliştirdiği kişilik envanterine (16PF) 1şık tutmuş̧tur.

Psikolojinin insan davranışını tanımlama fonksiyonu diğer disiplinlere de yardımcı olmaktadır. Özellikle fen bilimlerinin yanı sıra (Billings vd., 1992, Plomin vd., 1994, Beauchaine vd.,2008; Charney, 2016) sosyoloji, ekonomi gibi sosyal bilimlerde de insan davranışları önemini korumaktadır. Neo-Klasik yönetim anlayışında birey ve grup içindeki bireyin davranışlarına yönelik değerin artmasına öncülük eden Mary Parket Follett, Chester Bernard ve Douglas McGregor gibi bilim insanlarına daha sonraları bireyin psikolojik özellikleriyle de katkı yapan Kurt Lewin eklenmiştir. Bu gelişimi anlayabilmek için grup çalışmalarına ve bu grup çalışmalarının tarihselliğine de değinmekte fayda vardır. Neden grup çalışmaları ve sonucunda birey(ler) önem kazanmıştır? Bu sorunun yanıtı bu çalışma dâhil diğer tüm grup çalışmalarının daha iyi anlaşılmasına yönelik bize yardımcı olacaktır.

1930'lar ve 1940'lar boyunca birçok Avrupalı sosyal psikolog, alanlarındaki en önemli gelişmeler tarafından etkilendikleri Kuzey Amerika'ya gitmişlerdir. Amerika'ya giden bu bilim insanlarının çalışmalarını öncelikle zarar gördükleri Nazizm ve II. Dünya savaşı şekillendirmiştir (Singh, 2019:23). Neo-Klasik yönetim anlayışının bir yansıması olarak insan unsurunu ön planda tutan "grup dinamikleri" okulunun temelini teşkil eden çalışmalara ilk olarak Elton Mayo ve arkadaşları tarafından Western Elektrik Şirketinde 1920-1930 yılları arasında yapılan deneylerle başlanmıştır (Mayo,1945). Bu deneylerin temel amacı verimliliğin artırılmasına yönelik insan unsurunu ön plana çıkarmaktır. Kendisi de bir Yahudi olup 1933 yılında Nazizm'in pençesinden kurtulan Kurt Lewin (Marrow, 1969:73) yukarıda da belirtildiği üzere "grup dinamikleri" hareketinin kurucusu olarak grup içerisindeki bireysel davranışlar üzerinde kendisinden önce gelenlerin yaptıkları çalışmaları geliştirmiştir. İnsanların olumlu ya da olumsuz bir şekilde kendi başlarına elde edemeyecekleri belirli şeyleri elde etmek için bir grup içerisinde beraberce hareket ettikleri durumu ifade etmek amacıyla kullanılan "grup dinamikleri" (Goyal, 2010:84), çalışmanın diğer bir konusunu teşkil eden "grup uyumu" kavramını da içermektedir. Yine grup uyumu kavramının ve bu alanda yapılan deneylerin temelini Kurt Lewin'in çalışmaları oluşturmaktadır.

Güvenlik personeli, ister özel ister devlet sektöründe olsun, günlük görevlerini yerine getirirken genel olarak grup veya ekip şeklinde hareket etmektedirler. Dolayısıyla özel güvenlik hizmetleri de polislik gibi bir birliktelik işidir denilebilir. Güvenlik hizmetinin doğasında bulunan tehlike güvenlik hizmetini sunan personeli uyumlu ekiplerde çalışmaya yöneltmektedir. Genel olarak yazın incelendiğinde grup uyumuna etki eden faktörler içerisinde kişilik üzerine yapılan çalışma neredeyse hiç yoktur denilebilir. Bu nedenle bu çalışmanın amacı dışadönük kişilik özelliğinin grup uyumu üzerindeki etkisini araştırmaktır. 


\section{KAVRAMSAL ÇERÇEVE}

\subsection{Dışa Dönük Kişilik Üzerine}

Yukarıdaki tarihsel açılamada da belirtildiği üzere insan kişiliği uzunca bir süre bilim insanlarını meşgul etmiş ve hâlihazırda etmektedir. Özellikle I. Dünya savaşının sonu itibarıyla insanların davranış ve deneyimlerindeki değişiklikler sonuç olarak bilim insanlarını kişilik üzerine yoğunlaşmaya yöneltmiş̧ir zira bu dönemde ağırlıklı olarak kişiliğin sınıflandırılması ve tespitine yönelik çalışmalar yer almaktadır. Kişilik sınıflandırmalarından biri olarak karşımıza çıkan "dışadönük kişilik özelliği" ilk olarak Carl Jung (1926) tarafından ortaya atılan bir kavram olmasına karşın, diğer kişilik tipleri ile birlikte Gordon W. Allport ve Henry S. Odbert tarafından yapılan araştırmada inceleme konusu yapılmıştır (1936). Allport ve Odbert, kişilik özelliklerinin belirlenmesinde ve sinıflandırılmasında bu özelliklere isim verirken, bireylerin gündelik davranış dışavurumlarının yanı sıra tarihi geçmişten de yararlanmışlardır. Örneğin Protestan Devrimiyle birlikte insanın iç özelliğini yansıtan samimi, dindar, bağnaz, titiz, fanatik, özsaygı, özgüven, kendinden emin, izzetinefis gibi kelimelerin ortaya çıtı̆̆ı̆ı belirtmektedirler (Allport ve Odbert, 1936:2). Kısaltılmış Webster sözlügünden yaptıkları sınıflandırmaya göre 17.953 kişilik özelliği tespit eden Allport ve Odbert, sonraki çalışmalar için donanımlı bir veri tabanı oluşturmuşlardır. Allport ve Odbert yaptıkları çalışmada kişilik özelliklerinin alt yapısını hazırladıkları halde, bu özelliklerin gündelik hayatta ve bilimsel çalışmalarda pek de kullanılabilir olduğundan bahsetmek mümkün olmamıştır. Diğer bir ifade ile bu özelliklerin belirgin üst başlıklar altında toplanması gerekmiştir. Bu toplama işlevi de Raymond B. Cattell tarafından gerçekleştirilmiştir. Cattell, "özellikler küresi" (traits sphere) adını verdiği Allport ve Odbert tarafından belirtilen kişilik özelliklerini içerir uzun listeyi (1943:482) başlangıç noktası alarak bunları öncelikle 171 tanımlayıcı üst başlık altında toplamıştır. Daha sonradan yaptığı çalışmalar ile bunları bir başka değerlendirmeye tabi tutarak 46 yüzeysel kişilik özelliğine indirgemiştir (1957:813). Bu 46 kişilik özelliği daha sonradan karşılıklı korelasyon analizine tabi tutulmuş ve Cattell'in yazına kazandırdığı 16 kişilik faktörü (16PF) ortaya çıkmıştır. Cattell'in 16 kişilik faktörü ilerleyen dönemde farklı bir çalışma ile "büyük beşli" (Big Five) şeklinde tekrar isimlendirilmiştir. Bu isimlendirme Cattell'in kendisi dâhil farklı bilim adamları tarafından farklı şekillerde ifade edilmiştir (Goldberg, 1990, McCrae ve Costa 2004).

Tablo 1. Üç Ana “Beş Faktör Modeli”nin Sıralanışı

\begin{tabular}{|c|c|c|}
\hline $\begin{array}{c}16 \text { PF } \\
\text { (Cattell) }\end{array}$ & $\begin{array}{c}\text { NEO-PI-R } \\
\text { (Costa ve McCrae) }\end{array}$ & $\begin{array}{c}\text { Büyük Beş } \\
\text { (Goldberg) }\end{array}$ \\
\hline Dışa Dönüklük/İçe Dönüklük & Dışa dönüklük & Uysallık \\
\hline Düşük Endişe/Yüksek Endişe & Sinirsellik & Duygusal Dayanılılık \\
\hline Sertlik/Uysallık & Açılık & Kavramak veya Kültür \\
\hline Bağımsılık/Uzlaşmacılık & Anlaşabilirlik & Anlaşabilirlik \\
\hline Öz kontrol/Kısıtlama Eksikliği & Merhamet & Merhamet veya Güvenilebilirlik \\
\hline
\end{tabular}

Kaynak: Essentials of 16PF Assesment s.9

Konuya kavramsal analiz açısından bakıldığında ise yukarıda da belirtildiği üzere dışa dönük kişilik kavramını ilk ortaya atan kişinin Carl Jung olduğu anlaşılmaktadır. Jung dişa dönük kişilik özelliğini açıklamak suretiyle tanımlamaya çalışmıştır (1926:430). Ona göre, herhangi bir objeye ya da objektif gerçeğe odaklanma yoğunluğunda sübjektif değerlerden çok objektif ilişkilere göre gerekli harekete karar verildiğinde ve karar alındığında dışadönük tavırdan bahsedilir. Dışadönük kişilik özelliğinin tanımı Jung'dan sonra McDougall, Conklin tarafından da tanımlanmıştır. McDougall'a göre (1933:184) dışadönük kişi, etkin bir dürtüyü, en üst seviyede zihinsel bir süreç ile kontrol ya da değişime sokmadan harekete geçirme ve ifade etmeye hazır bir kişidir. Conklin'e göre (1927:28) ise dışadönük kişilik "dikkatin sübjektiften çok objektif şartlarla kontrol edildiği ve sübjektif şartların içeriğinin daha çok objektif şartlarla ilişkili olduğu" şeklinde açıklanmaktadır. Her üç bilim insanının tanımlarından da anlaşıldığı üzere dışa dönük kişilik genel olarak dış dünyada bulunan objektif şartlara gösterilen ifade ve hareketler olarak karşımıza çıkmaktadır.

Burada dışadönük kişilik özelliğinin muhteviyatından da bahsetmek gerekmektedir. Carl Jung dışadönük kişilik özelliğinin dört faktör altında değerlendirmiştir. Bunlar düşünme (thinking), hissetme (feeling), duyumlama (sensation), ve önsezi (intuition)'dir (1926:428-470). Bu başlıklar altında dişadönük kişilik özelliği, bireyin kendisini, dış dünyadaki durumda (olay, olgu, vb.) hissetmesi, duyumlaması veya düşünmesi olarak 
düşünülebilir. Diğer bir ifade ile dışarıdaki obje bireyi yönlendirmektedir (Jung, 1926:542). Bu ifadeden yola çıkarak dışadönük kişiliğin davranış kalıpları olarak sosyallik, etkileyicilik, enerjik, macera düşkünü, ilham verici ve samimilik'ten bahsedilebilir (McCrae \& John, 1992:178).

\subsection{Grup Uyumu Üzerine}

Yukarıda da açıklandığı üzere gruplar üzerine çalışmalar genel olarak ekonomik temelli olup, sonucunda verimin artırılmasının insani unsurların ön plana çıkarılmasıyla gerçekleşebileceği düşüncesinden hareketle başlamıştır. Bu kapsamda 1940'larda grup içinde bireylerin nasıl davrandıklarının yanı sıra bu davranışların bir bileşkesi olan grup uyumunun da grup çalışmalarında ayrı bir yeri olagelmiştir (Hogg, 1993:85). 1950'lerde grup çalışmaları genel olarak küçük gruplar üzerinde ve yüz yüze ilişkisi bulunan grup üyeleri arasındaki ilişkileri tanımlamak üzere laboratuvar şartlarında yapılmış olmakla birlikte (Roseborough, 1953:275) bu durum zamanla değişmiş ve doğal şartlarda çalışmalar yapılmıştır. Bu kavram 1960'larda neredeyse unutulmuş 1970'lerden itibaren tekrar üzerinde araştırma yapılan konulardan olmaya başlamıştır (Mudrack, 1989:37).

Latince "birbirine bağlanmak" anlamına gelen "cohaesus" kelimesinden geldiği belirtilen ve İngilizce karşılığ 1 "cohesion" olan uyum kavramının grup çalışmaları içerisinde önemli bir yeri vardır. Kavram geniş bir anlam alanı barındırdığından "bizlik (we-ness)", "aidiyet (belongingness)", "ilgi duyma (attraction)", "moral (morale)", "grup kişiliği (syntality)" ve "dayanışma (solidarity)" gibi kelimelerle de aynı anlamda kullanılmıştır (Fine \& Holyfield, 1996:22, Dion, 2000:7). Grup uyumu kavramı öncelikle Kurt Lewin tarafından ortaya atılan açıklamalarla karşımıza çıkmaktadır. Lewin bu kavramı doğrudan tanımlamak yerine benzerlik, farklılık, grup aidiyeti, karşılıklı bağımlılık gibi farklı terminolojileri kullanmıştır. Ona göre grup içerisinde farklı bireyler aynı (veya çok benzer) davranışları gösterebilirler. Bu durum aynı zamanda çevrenin ve bireylerin kabulleri ile ilgilidir (1935:72). Grup belirli benzerlikler gösteren ve benzer tavırlar sergileyen insanların birlikteliği anlamına gelmekle birlikte burada benzerliğin yanı sıra grup aidiyetinden de bahsedilmektedir. Fakat bu aidiyetten kaynaklanan benzerlik tam olarak grubu açıklamamaktadır. Grup üyeleri arasında benzerlik olmasa bile karşılıklı bağımlılık da olmalıdır (1939:886-887).

Grup uyumunun tanımsal ifadesi ilk olarak Moreno ve Jennings tarafından yapılmıştır. Yaptıkları tanıma göre grup uyumu "üyeleri, içinde bulundukları birliktelikte tutan faktörler" dir (1938: 371). Grup uyumuna yönelik diğer bir tanım ise Festinger ve arkadaşları yapılmıştır (1950). Yaptıkları araştırmada Festinger ve arkadaşları kısaca Massachussetts Teknoloji Enstitüsündeki öğrencilerin yerleşim çevrelerindeki grup dinamikleri üzerinde yoğunlaşmışlar ve grup uyumunu "üyelerin grupta kalmalarına yönelik hareket eden toplam faktör alanları" olarak tanımlamışlardır (1950a:164). Fakat yine Festinger tarafından aynı yıl yapılan diğer bir araştırmada ise grup uyumu "grupta kalmaları için üyeler üzerinde hareket eden bütün faktörlerin sonucu" olarak tanımlanmıştır (1950b:274). Grup haricindeki dış faktörleri referans alan bu tanımlar diğer bilim insanları tarafından başlangıç noktası oluşturmuştur. Gross ve Martin ise grup uyumunu "birbirine yapışmakbirlikte olmak" (sticking-togetherness) kavramları ile özetleyerek daha grup merkezli bir şekilde "rahatsız edici baskılara karşı grubun direnci" olarak ifade etmişlerdir (1952:553). Dikkat edilecek olunursa Moreno ve Jennings ile Festinger ve arkadaşları ve Festinger'in kendisi ile birlikte Gross ve Martin'in tanımları hemen hemen aynıdır. Bu durum diğer araştırmacılara göre büyük bir yanlışlık olarak değerlendirilmiştir (Mudrack, 1989:41) Burada grup uyumu kavramının tanımsal ifadesi ile ilgili olarak iki farklı çalışmadan daha bahsetmek gerekir. Bunlardan birincisi Van Bergen ve Koekebakker tarafından yapılan çalışmadır (1959:85). Adıgeçen bilim insanlarına göre grup uyumu "grup alanının birleşme derecesi"dir. Bu tanım daha çok Kurt Lewin tarafından yapılan açılamalara benzemektedir. Diğer bir tanım ise Lott ve Lott tarafından yapılan çalışma sonucunda ifade edilmektedir. Bu tanıma göre grup uyumu "grup üyeleri arasındaki karşllıklı pozitif tavırların gücü ve sayısından kaynaklanan grup niteliği"dir (1965:259).

Grupların temelini insan unsuru, insan unsurunun temelini de birbirleri arasında zamanla gelişen ilişkiler teşkil eder (Bettenhusen, 1991:351). Bu itibarla grup uyumu açısından insan unsurunun iki davranış özelliğinden bahsetmek gerekir. Bunlardan birincisi insanların bir gruba üye olmalarının ana nedenlerinden birinin grubun amaçları ve başarmaya çalıştığı görevleri olmasıdır. "Araçsal uyum" olarak adlandırılan bu durumda birey, grubun amaç ve görevlerini kendi amaç ve görevleri ile özdeşleştirmektedir ve o nedenle gruba eklemlenmek istemektedir. İkincisi ise daha çok sosyal içerikli olup burada grup, üyesi olan veya olacak olan bireye benlik, tanınma veya güvenlik gibi bir dizi duygusal tatmin sağlamaktadır. Bu da "sosyo-duygusal 
(socioemotional) uyum" olarak adlandırılmaktadır (Tziner, 1982:237-238). Bu sınıflandırma Lott tarafından yapılan çalışmadaki (1961:277-278) temel varsayımlar üzerine kurulmuştur. Bu varsayımlara göre insan temelde araçsal olarak davranmaya meyillidir. Diğer bir ifade ile insan amaç odaklıdır. Grubun ilgi çekiciliğinden bahsedildiğinde aslında grup içindeki bireylerin ilgi çekiciliğinden bahsedilmektedir. Burada da bireylerin gruba dâhil olmak için geçerli sosyo-duygusal nedenleri oluşmaktadır. Lott ve Tziner tarafından yapılan bölümlemeler, daha sonradan Severt ve Estrada tarafından uyumun grup içerisinde izlediği yöne göre ele alınmıştır. Söz konusu çalışmada grup üyelerinin kendileri ile aynı seviyedekilerle olan uyumu yatay uyum, üstleri ile olan uyumları da dikey uyum olarak adlandırılmış, hem yatay hem de dikey uyumda sosyal ve araçsal faktörler ele alınmıştır (2015:8). Bu açıklamalar bizi grup uyumunun bileşenlerine götürmektedir. Bunlar;

a-Grup üyelerine ilgi duyma (Forsyth, 1983:349)

b-Grubun araçsal değerleri,

c-Grup içerisinde oluşan riskleri kabul etme ( Stokes, 1983:164)

d-Grup faaliyetlerinin tatminkârlığı (Hogg \& Hardie, 1992:41)'dır.

Önceden de belirtildiği üzere amaç odaklı olan birey, amacını gerçekleştirmek için dâhil olduğu grubun üyelerine ilgi duymakta, araçsal değerlerini ve grup içerisinde oluşan veya oluşabilecek olan riskleri grup faaliyetlerini tatminkâr görerek kabul etmektedir. İster araçsal olsun ister sosyo-duygusal olsun, her ne sebeple bir grup oluşturulmuş ise orada bir dereceye kadar uyumun varlığından söz edilebilir (Carron \& Spink, 1995:86). Zira insanlar grupları oluştururken ortak amaçlarının yanı sıra ortak duygulara da sahiptirler (Hogg, 1993:87). Grup uyumunun içeriğine göz atıldığında, bu kavramın; başarı ve başarısızlık, cinsiyet, espri yeteneği, kişiliksizleştirme, örgütsel bağlllık, etnosentrizm, normatif yönetim, grup içi güven, saygı ve hoşlanma, grup dayanışması ile gruplar arası farklılığı içerdiğini de görmekteyiz (Bettenhausen, 1991: 362,Hogg ve Hardie, 1991:175, Hogg, 1993:94).

Grup uyumu üzerine yapılan araştırmalara baktığımızda aslında neden bu kadar özenle üzerinde durulduğu rahatça anlaşılabilmektedir. Grup uyumunun ekonomik terminoloji ile daha fazla ilişkilendirilmesi onun daha çok ekonomik amaçlarla çalışma konusu yapıldığını ortaya koymaktadır. Örneğin grup uyumu daha çok, performans, verimlilik, lider davranışı ve astların tatmini, iş tatmini (Mullen \& Copper, 1994, Carless \& Paola, 2000, Beal vd., 2003, Evans \& Dion, 2012, Gully vd., 2012, Greene, 1989, Dobbins \& Zaccaro, 1986) gibi kavramlarla ilişkilendirilmeye çalışılmıştır.

Grup uyumu örgütsel performansı veya verimliliği belirli faydaları yerine getirerek sağlamaktadır. Bu anlamda grup uyumu; örgütsel kültürü (Fine ve Holyfield, 1996:22), örgütsel normları (Horne, 2001:254), grup üyelerinin tatminin artmasını, grup içinde sorumluluk duygusunun gelişmesini, grup üyeleri arasındaki iletişim yoğunluğu ile grup üyelerinin görev ve amaç merkezli çalışma isteğinin artmasını sağlamaktadır (Organ ve Bateman, 1986:473-474).

Grup uyumu üzerine yapılan son dönem bilimsel çalışmalarda en önemli yeri Carron'un yaptığı araştırmalar oluşturmaktadır (Carron, 1982, Carron vd., 1985, Carron ve Spink, 1995, Carron ve Brawley, 2002, Carron vd., 2002, Carron vd., 2004). Grup uyumunu "amaç ve hedeflere ulaşmada grubun birbirine bağlanması ve birlik olarak kalmasına yönelik eğilim" olarak tanımlayan Carron (1982:124) ve çalışma arkadaşları yaptıkları tüm bu çalışmaları spor takımları üzerinde yapmışlardır. Bu çalışmalarında öne sürdükleri ana tema uyum konusunda grup ve bireyin ayrı tutulması gerektiğidir. Bu amaçla "grup çevre anketi" ni (Group Environment Questionnaire-GEQ) geliştirmişlerdir. Her ne kadar bu anket adı geçen bilim insanlarınca spor takımları üzerinde denenmiş ve kabul görmüş ise de aynı anket askeri birlikler üzerinde de denenmiş ve güvenilir olduğu görülmüştür (Griffith, 1988, Ahronson ve Cameron, 2007). Bu çalışmamızda Carron ve arkadaşları tarafından geliştirilmiş olan grup çevre anketi de kullanılacaktır.

\section{3-Güvenlik Hizmetlerinde Dışa Dönük Kişilik Özelliği}

Ekonomide kapitalizmin etkilerini görünür kılan sektörlerden biri de özel güvenlik sektörüdür. Dünya üzerindeki insan sayısının ve buna bağlı olarak da insan ihtiyaçlarının artması, devletlerin bu ihtiyaçları zamanında ve etkin olarak yerine getirememesi gibi problemlere neden olmaktadır. Güvenlik hizmeti de bunlardan biri olarak karşımıza çıkmaktadır. Özel güvenlik hizmetlerine bakıldığında polise yardımcı, var 
olan güvenlik ihtiyacının eksikliğinin giderilmesine bir çare olarak düşünüldüğü anlaşılmaktadır. Konuya tarihsel açıdan bakıldığında özel güvenlik hizmetlerinin oluşturulmasılla güvenlik hizmetlerinde geriye dönüşün olduğu anlaşılabilir. Şöyle ki: Polis örgütleri ilk olarak Fransa ve İngiltere' de kamusallaşmadan önce özel güvenlik olarak ortaya çıkmıştır. Sermaye sahiplerinin kurdukları bu oluşumların personeline daha fazla para ödememek ve kendilerinin sadece işyerlerinde değil, toplum içerisinde de güvenlikli şekilde yaşamlarını sağlayabilmek için özel güvenlik için oluşturdukları yapıları topluma mal ederek modern polis örgütlerinin ilk tohumlarını atmışlardır (Şimşek, 2015).

$\mathrm{Bu}$ açıdan bakıldığında özel güvenlik ve polisliğin benzer karakteristikleri paylaştıkları düşünülebilir. Bu durum örgüt yapıları açısından tam olmamakla birlikte, personelin eğitim ve düşünsel yapıları açsından aynı olarak düşünülmelidir. Zira polisler gibi özel güvenlik personelinin temel odağını insan unsuru teşkil etmektedir. Kısaca özel güvenlik de polislik gibi insanların bulunduğu yerde icra edilen bir meslektir. Fakat günümüzde özel güvenlik personeli üzerinde yapılan araştırmalar yeterli değildir. Dolayısıyla özel güvenlik personelinin dışadönük kişilikleri ile ilgili analizde polisler üzerine yapılan çalışmalardan faydalanmak yerinde olacaktır.

İster özel ister kamusal olsun güvenlik örgütlerinin uğraş alanını, insan ve insanların oluşturdukları topluluklar olarak tanımlamak gerekir. Kısaca insan var ise güvenlik örgütleri ve onların personeli vardır. Skolnick (1966), Niederhoffer (1967) ve Balch (1972) tarafından belirlenen polis kişilik özelliklerine derinlemesine bakıldığında, bu özelliklerin dışadönük kişilik özelliği ile birbirlerini tamamladığı görülebilmektedir. Bunlar üzerinde yapacağımız bir analiz araştırmanın daha iyi anlaşılmasında bizlere yardımcı olacaktır.

Güvenlik hizmetlerinde çalışmak dünya üzerindeki en zor işlerden biridir. Bunu zor yapan unsurların başında "tehlike" faktörü gelmektedir (Balch,1972:110, Skolnick, 2010:22). Tehlike ile her an karşı karşıya kalma ihtimali bulunan güvenlik personeli zamanla dış çevrelerini belirli bir sınıflandırmaya göre algılamaya başlamaktadırlar. Onlara göre dış çevreleri tehlikeli veya tehlikesiz, faydalı veya faydasız, dost veya düşmandır. Bu çevre ister istemez güvenlik personelini kinik (Cynic) (Balch, 1972:111) davranış şekline itmektedir. A Tipi olarak tanımlanan davranış şekli (Rosenman, 1978) içerisinde de yerini bulan kinik davranış, kendi içerisinde; maçoluk, muhafazakârlık, şiddet, gizlilik ve şüphecilik gibi güvenin az olduğu tavırları kapsamaktadır (Şimşek, 2015:265). Güvenlik hizmetlerinde en önemli görev tavırlarından biri şüpheciliktir. Şüpheciliğin birincil özelliği çevredeki sıradan hale gelmiş olan şeylerin anormal veya beklendiğinden farklı olduğunun algılanmasıdır. Bu algılamanın ardından güvenlik personeli, şüphelendiği konu ile ilgili olarak gerekli kararı hemen verebilmelidir. Dikkat edilirse dışarıdaki şüpheli durum güvenlik personelini harekete geçirmekte ve onun bir an önce karar almasına neden olmaktadır. Bu açıklama dışadönük kişilik özelliğinin tanımına da uymaktadır.

Güvenlik personeli mesleklerinin fonksiyonu gereği diğer insanların belirli kurallara uymalarını sağlarlar. Bu durum onların diğer insanlara hükmetmelerine neden olmaktadır. Kişilik olarak polisler bu fonksiyona paralel olarak "otoriter" bir kişilik yapısını sergilemektedirler. Buradaki konumuz otoriter olan kişilerin mi güvenlik hizmetini tercih ettikleri ya da güvenlik mesleklerinin mi polisleri otoriterliğe ittiği değildir. Sonuç itibarı ile özel güvenlik personeli de polisler gibi kamu düzeninin sağlanması için otoriter olmak durumundandırlar. Adorno ve arkadaşları tarafından yapılan araştırmada (1950) otoriter kişilik özelliği sergileyen kişilerin içedönük davranıştan çok dışadönük davranış sergiledikleri ortaya koyulmuştur.

Güvenlik hizmeti sağlayan personel ile ilgili olarak konumuzla ilgili diğer bir kavram da sosyal izolasyondur (Clark, 1965, Skolnick, 2010:20-21). Her meslek mensubunun kendine özgü birlikte olduğu bir arkadaş çevresi bulunmaktadır. Bu çevre yapılan mesleğin fonksiyonu ile yakından ilgilidir. Güvenlik mesleklerinde, tehlikeye maruz kalmak onların toplumdan kendilerini soyutlayarak belirli birliktelikler kurmalarına neden olmaktadır. Aslına bakılacak olunursa bu durum yukarıda belirtildiği üzere toplumu kategorize etmenin sonuçlarından biri olarak da görülebilir. Güvenlik personelinin dışadönük kişilik özelliklerinden biri olarak görülebilecek olan dayanışma duygusu, dış çevrelerine karşı aldıkları tavrın görünen yüzüdür. Çevrelerinde gördükleri tehlikeleri ancak kendilerinden olan birileri ile birliktelik kurarak giderme düşüncesindedirler. Diş çevreleri onları bu tür birliktelikler kurmaya sevk etmektedir. 
Tüm bu açıklamalar ışığında konuya özel güvenlik personeli açısından bakıldığında fonksiyonel olarak polisten farklı bir iş yapmayan özel güvenlik personelinin de aynı duyguları paylaşıp benzer kişilik özelliklerine sahip olabilecekleri düşünülebilir.

\section{YÖNTEM}

\subsection{Araştırma Modeli}

Dışadönük kişilik özelliğinin grup uyumu üzerindeki etkisinin araştırılması ve bu kavramların demografik değişkenler açısından incelemesi amacıyla oluşturulan araştırma modeli Şekil 1'de yer almaktadır.

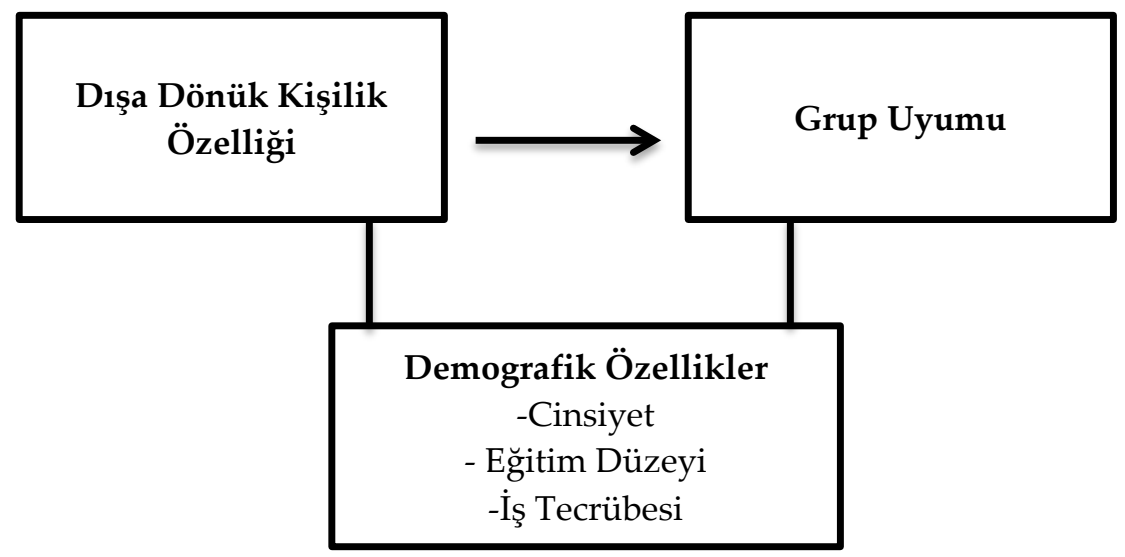

Şekil 1: Araştırma Modeli

Araştırmanın hipotezleri aşağıdaki gibidir:

H1a: Özel Güvenlik çalışanlarının dışa dönük kişilik özelliği düzeyi cinsiyete göre anlamlı bir farklılık göstermektedir.

H1b: Özel Güvenlik çalışanlarının dışa dönük kişilik özelliği düzeyi eğitim düzeyine göre anlamlı bir farklılık göstermektedir.

H1c: Özel Güvenlik çalışanlarının dışa dönük kişilik özelliği düzeyi iş tecrübesine göre anlamlı bir farklılık göstermektedir.

H2a: Özel Güvenlik çalışanlarının grup uyumu düzeyi cinsiyete göre anlamlı bir farklılık göstermektedir.

H2b: Özel Güvenlik çalışanlarının grup uyumu düzeyi eğitim düzeyine göre anlamlı bir farklılık göstermektedir.

H2c: Özel Güvenlik çalışanlarının grup uyumu düzeyi iş tecrübesine göre anlamlı bir farklılık göstermektedir.

H3: Özel Güvenlik çalışanlarının dışa dönük kişilik özelliğinin grup uyumu üzerinde anlamlı bir etkisi vardır.

\subsection{Evren ve Örneklem}

Özel güvenlik personeli toplumsal alanda bireylerle sürekli bir etkileşim halinde bulunmaktadır. Bu etkileşim özel güvenlik personelinin çekingen veya içine kapanık olmaktan çok görevleri gereği dışa dönük kişilik özellikleri göstermelerini gerektirmektedir. Araştırmanın örneklemi amaçlı örnekleme yöntemlerinden, kolayda örnekleme yolu ile seçilmiştir. Kolayda örneklemde araştırma öğeleri araştırmacının araştırmanın özelliklerine dayanarak oluşturduğu yargılara göre seçilmektedir (Gürbüz ve Şahin, 2015: 132). Araştırmanın evrenini Hakkâri' de çalışan 443 özel güvenlik personeli, örneklemini ise Hakkâri'de çalışan 351 özel güvenlik personeli oluşturmaktadır. Örneklem büyüklügünün 200'ün üzerinde olması güvenilir faktörlerin elde edilmesi için genellikle yeterli görülmektedir. Ayrıca ölçekteki madde sayısının 10 katı kadar bir örneklemle çalışılması tavsiye edilmektedir (Gürbüz ve Şahin, 2015: 128). Ölçekteki madde sayısının 26 olması nedeniyle örneklem sayısının araştırma için yeterli olduğu ifade edilebilir. Araştırmanın veri toplama süreci 23.08.201801.09.2020 tarihleri arasında tamamlanmıştır. 


\subsection{Veri Toplama Araçları}

Çalışmamız özel güvenlik personelinin örgütsel kimlik algılarının örgütsel bağlılık düzeylerine olan etkisinin test edilmesi amacıyla ilişkisel tarama modeliyle yapılmıştır. "İlişkisel tarama modeli, iki ve ikiden fazla sayıdaki değişim durumunu ve bu değişimin derecesini belirtmeyi amaç edinen bir çalışma ve araştırma modelidir" (Karasar, 2016). Araştırmada kullanılan anket üç bölümden oluşmaktadır. İlk bölümde demografik değişkenlere ilişkin sorular yer almaktadır. İkinci bölümde Oliver P. John ve Sanjay Srivastava (1999) tarafından geliştirilen ve 44 maddeden oluşan "Beş Faktör Kişilik Ölçeği" sorularından faydalanılmıştır. Anketin üçüncü bölümünde "Grup Uyumu" değişkenine ait sorular yer almaktadır. Grup uyumunu ölçmek için Carron vd. (1985) tarafından geliştirilen 18 maddeden oluşan ölçek kullanılmıştır. Anket formunu oluşturan ölçek sorularının cevapları beşli Likert ölçeğine göre derecelenmiştir. Derecelendirmeler "1kesinlikle katılmiyorum, 2-katılmıyorum, 3-orta derecede katılıyorum 4-katıllyorum, 5-kesinlikle katılıyorum" şeklindedir.

Dışa dönük kişilik özellikleri ölçeğinin geçerlilik ve güvenilirliğinin test edilmesi amacıyla keşfedici faktör analizi ve güvenilirlik analizi uygulanmıştır. Analiz sonuçları şu şekildedir:

Tablo 2. Dışa Dönük Kişilik Özellikleri Ölçeğinin Güvenilirliğine İlişkin Bulgular

\begin{tabular}{llc}
\hline$\underline{\text { Faktör }}$ & $\underline{\text { Iffade }}$ & Güvenilirlik Katsayısı \\
& DD1 & \\
DD3 & \\
DD4 & 0,755 \\
DD6 & \\
DD8 & \\
& \\
Kaiser-Mönük Kişilik Özellikleri & \\
Bartlett Küresellik Testi p Değeri: 0,000 & \\
\hline
\end{tabular}

Tablo 2'de görüldüğ ü üzere, dişa dönük kişilik özellikleri tek boyut altında toplanan 5 ifadeden oluşmaktadır. Ölçeğin geçerlilik (KMO=0,784, p=0,000) ve güvenilirliği (Cronbach's Alpha=0,755) sağlanmıştır.

Grup uyumunun geçerlilik ve güvenilirliği, yine keşfedici faktör analizi ve güvenilirlik analizi kullanılarak test edilmiştir. Analiz sonuçları aşağıdaki tabloda özetlenmiştir:

Tablo 3. Grup Uyumu Ölçeğinin Güvenilirliğine İlişkin Bulgular

\begin{tabular}{|c|c|c|c|c|}
\hline Faktör & İfade & Faktör Yükü & Açılanan Varyans & Güvenilirlik Katsayısı \\
\hline Grupla Görev Bütünlüğü & $\begin{array}{l}\text { UY12 } \\
\text { UY9 } \\
\text { UY15 } \\
\text { UY10 } \\
\text { UY16 }\end{array}$ & $\begin{array}{l}0,726 \\
0,718 \\
0,707 \\
0,695 \\
0,676\end{array}$ & 31,636 & 0,759 \\
\hline Grubun Sosyal Çekiciliği & $\begin{array}{l}\text { UY3 } \\
\text { UY2 } \\
\text { UY4 }\end{array}$ & $\begin{array}{l}0,828 \\
0,797 \\
0,781\end{array}$ & 25,084 & 0,742 \\
\hline \multicolumn{5}{|c|}{$\begin{array}{l}\text { Kaiser-Meyer-Olkin Örneklem Yeterliliği: 0,790 } \\
\text { Bartlett Küresellik Testi p Değeri: 0,000 } \\
\text { Toplam Açıklanan Varyans: 56,720 }\end{array}$} \\
\hline
\end{tabular}

Tablo 3'de görüldüğü üzere grup uyumu 2 faktörden oluşmaktadır. Ölçeğin geçerlilik (KMO=0,790, p=0,000) ve güvenilirliği ( $\alpha$ Grupla Görev Bütünlüğü=0,759, $\alpha$ Grubun Sosyal Çekiciliği=0,742) sağlanmıştır. 


\section{BULGULAR}

Dışa dönük kişilik özelliğinin ve grup uyumunun demografik değişkenlerle ilişkisini ortaya koymak amacıyla yapılan analizlerde SPSS 25 nicel analiz programı kullanılmıştır.

Katılımcıların demografik özelliklerini ortaya koymak amacıyla frekans analizi yapılmıştır. Analiz sonuçları Tablo 4'de görülmektedir.

Tablo 4. Katılımcıların Demografik Özellikleri

\begin{tabular}{lccc}
\hline \multirow{2}{*}{ Cinsiyet } & & $\mathbf{n}$ & $\%$ \\
& Kadın & 49 & 14,0 \\
Eğitim Durumu & Erkek & 302 & 86,0 \\
& Ortaokul & 7 & 2,0 \\
& Lise & 264 & 75,2 \\
İş Tecrübesi & Üniversite & 80 & 22,8 \\
& 2 Yılın altında & 36 & 10,3 \\
& $3-5$ Yıl & 57 & 16,2 \\
& 6-9 Yil & 108 & 30,8 \\
& 10 Yll ve Üzeri & 150 & 42,7 \\
\hline
\end{tabular}

Tablo 4'de görüldüğü üzere anketi cevaplayanların \%14,0'ü kadın; \%86,0'sı erkek \%2'si ortaokul, \%75,2'si lise mezunu, \%22,5'i üniversite mezunu, \%0,3'ü lisansüstü eğitim mezunudur. Son olarak, katılımclların \% 10,3'ü 2 yıldan az, 16,2'si 3-5 yıl arası, \% 30,8'i 6-9 yıl arası, \% 42,7'si 10 yıl üzeri çalışma süresine sahiptir.

Dışa dönük kişilik özellikleri, grupla görev bütünlüğü ve grubun sosyal çekiciliğinin cinsiyete göre farklılık gösterip göstermediğini belirlemek üzere bağımsız gruplar $t$ testi yapılmıştır. Test sonuçları şu şekildedir:

Tablo 5. Dışa Dönük Kişilik Özellikleri, Grupla Görev Bütünlüğü ve Grubun Sosyal Çekiciliğinin Cinsiyete Göre Farklılığına İlişkin Bağımsız Gruplar t Testi

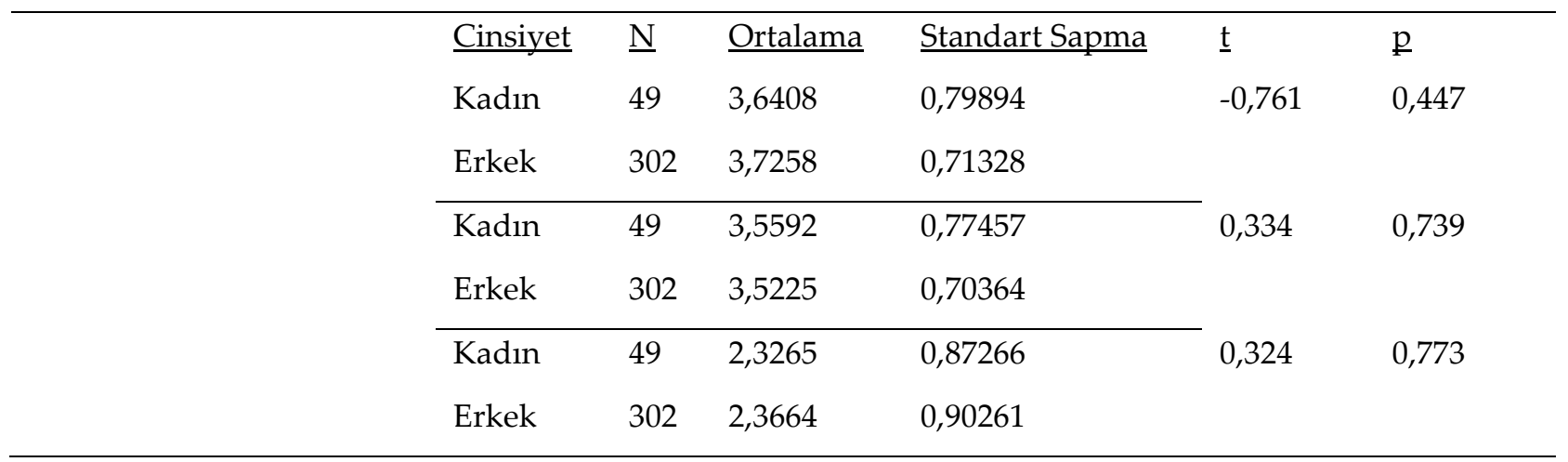

Tablo 5’te görüldüğü üzere, dişa dönük kişilik özellikleri, grupla görev bütünlüğü ve grubun sosyal çekiciliği cinsiyete göre farklılık göstermemektedir. Dolayısıyla analiz sonucunda çalı̧̧manın H1a hipotezinin desteklenmediği ifade edilebilir.

Dışa dönük kişilik özellikleri, grupla görev bütünlüğü ve grubun sosyal çekiciliğinin eğitim durumuna göre farklılık gösterip göstermediğini belirlemek üzere tek yönlü varyans analizi (ANOVA) uygulanmıştır. Analiz sonucunda dişa dönük kişilik özellikleri ve grupla görev bütünlüğünde eğitim durumuna göre istatistiksel olarak anlamlı bir farklılık tespit edilmemiştir. Grubun sosyal çekiciliği ise eğitim durumuna göre farklılık göstermiştir. Grubun sosyal çekiciliğine ilişkin sonuçlar Tablo 6'da açıklanmıştır. 
Tablo 6. Grubun Sosyal Çekiciliğinin Eğitim Durumuna Göre Farklılığına İlişkin Tek Yönlü Varyans Analizi (ANOVA)

\begin{tabular}{|c|c|c|c|c|c|}
\hline & & $\mathbf{N}$ & Ortalama & F Değeri & p Değeri \\
\hline \multirow{3}{*}{ Grubun Sosyal Çekiciliği } & Ortaokul & 7 & 2,4286 & \multirow{3}{*}{5,301} & \multirow{3}{*}{0,005} \\
\hline & Lise & 264 & 2,2740 & & \\
\hline & Üniversite & 80 & 2,6417 & & \\
\hline
\end{tabular}

Tablo 6’da görüldüğü üzere, grubun sosyal çekiciliği eğitim durumuna göre farklılık göstermektedir. Grubun sosyal çekiciliğindeki farklılık lise ve üniversite mezunlarından kaynaklanmakta olup, üniversite mezunlarında grubun sosyal çekiciliğinin daha yüksek olduğu ortaya çıkmaktadır. Dolayısıyla analiz sonucunda çalışmanın $\mathrm{H} 1 \mathrm{~b}$ hipotezinin kabul edilmediği, $\mathrm{H} 2 \mathrm{~b}$ hipotezinin kısmen desteklendiği ifade edilebilir.

Dişa dönük kişilik özellikleri, grupla görev bütünlüğü ve grubun sosyal çekiciliğinin iş tecrübesine göre farklılık gösterip göstermediğini belirlemek üzere tek yönlü varyans analizi (ANOVA) uygulanmıştır. Analiz sonuçları Tablo 7'de özetlenmiştir.

Tablo 7. Dışa Dönük Kişilik Özellikleri, Grupla Görev Bütünlüğü ve Grubun Sosyal Çekiciliğinin İş Tecrübesine Göre Farklılığına İlişkin Tek Yönlü Varyans Analizi (ANOVA)

\begin{tabular}{|c|c|c|c|c|c|}
\hline & & $\mathbf{N}$ & Ortalama & $\begin{array}{l}\mathrm{F} \\
\text { Değeri }\end{array}$ & $\begin{array}{l}\mathrm{p} \\
\text { Değeri }\end{array}$ \\
\hline \multirow{4}{*}{$\begin{array}{l}\text { Dişa Dönük Kişilik } \\
\text { Özellikleri }\end{array}$} & 2 yilın altında & 36 & 4,0778 & \multirow{4}{*}{6,957} & \multirow{4}{*}{0,000} \\
\hline & 3-5 yil & 57 & 3,4737 & & \\
\hline & $6-9$ yil & 108 & 3,8296 & & \\
\hline & $10 \mathrm{yll}+$ & 150 & 3,6347 & & \\
\hline \multirow{4}{*}{ Grupla Görev Bütünlüğü } & 2 yilın altında & 36 & 3,9444 & \multirow{4}{*}{5,613} & \multirow{4}{*}{0,001} \\
\hline & 3-5 yil & 57 & 3,5158 & & \\
\hline & 6-9 yil & 108 & 3,3926 & & \\
\hline & $10 \mathrm{y} 1 \mathrm{l}+$ & 150 & 3,5293 & & \\
\hline \multirow{4}{*}{ Grubun Sosyal Çekiciliği } & 2 yilın altında & 36 & 1,7500 & \multirow{4}{*}{6,914} & \multirow{4}{*}{0,000} \\
\hline & 3-5 yil & 57 & 2,5439 & & \\
\hline & $6-9$ yil & 108 & 2,4198 & & \\
\hline & $10 \mathrm{y} 1 \mathrm{l}+$ & 150 & 2,3956 & & \\
\hline
\end{tabular}

Tablo 7'de görüldüğü üzere, her üç değişkenin ortalamaları iş tecrübesine göre farklılık göstermektedir. Genel olarak dışa dönük kişilik özellikleri ve grupla görev bütünlügü iş tecrübesi arttıkça azalmakta, buna karşın grubun sosyal çekiciliği artmaktadır. Dolayısıyla analiz sonucunda çalışmanın H1c ve H2c hipotezlerinin desteklendiği ifade edilebilir.

Dışa dönük kişilik özelliğinin görev bütünlüğü üzerindeki etkisini belirlemek üzere basit doğrusal regresyon analizi yapılmıştır. Analiz sonuçları Tablo 8'teki gibidir. 
Tablo 8. Dışa Dönük Kişilik Özelliğinin Görev Bütünlüğü Üzerindeki Etkisine İlişkin Regresyon Analizi

\begin{tabular}{lcccccr}
\hline $\mathbf{R}$ & $\mathbf{R}^{2}$ & $\mathbf{F}$ & $\mathbf{p}$ & Beta & Standart Hata & t \\
0,286 & 0,082 & 31,170 & 0,000 & 0,281 & 0,050 & 5,583
\end{tabular}

Sabit: 2,482

Bağımlı Değişken: Görev Bütünlüğü

Tablo 8' de görüldüğü üzere, dışa dönüklüğün görev bütünlüğü üzerinde istatistiksel olarak anlamlı bir etkisi vardır. Regresyon eşitliği şu şekilde kurulabilir:

Görev Bütünlüğü: 2,482+0,2821çarpı dişa dönüklük

Dışa dönük kişilik özelliğinin grubun sosyal çekiciliği üzerindeki etkisini belirlemek üzere basit doğrusal regresyon analizi yapılmıştır. Analiz sonuçları Tablo 9'daki gibidir.

Tablo 9. Dişa Dönük Kişilik Özelliğinin Grubun Sosyal Çekiciliği Üzerindeki Etkisine İlişkin Regresyon Analizi

\begin{tabular}{lrrrrrr}
\hline $\mathbf{R}$ & $\mathbf{R}^{2}$ & $\mathbf{F}$ & $\mathbf{p}$ & Beta & \multicolumn{2}{c}{ Standart Hata } \\
0,154 & 0,024 & 8,490 & 0,004 & $-0,191$ & 0,065 & $-2,914$
\end{tabular}

Sabit: 3,069

Bağımlı Değişken: Grubun Sosyal Çekiciliği

Tablo 9’ da görüldüğü üzere, dişa dönüklüğün grubun sosyal çekiciliği üzerinde istatistiksel olarak anlamlı bir etkisi vardır. Regresyon eşitliği şu şekilde kurulabilir:

Grubun Sosyal Çekiciliği:3,069-0,191 çarpı dışa dönüklük

Dişa dönüklüğün görev bütünlüğü üzerinde pozitif, sosyal çekicilik üzerinde negatif bir etkisi olduğu tespit edilmiştir. Dolayısıyla araştırmanın H3 hipotezinin kabul edildiği ifade edilebilir.

\section{SONUÇ VE TARTIŞMA}

$\mathrm{Bu}$ araştırmada temel olarak Cattell (1943) ile McCrae ve Costa'nın (2004) kişilik üzerine yaptıkları çalışmalarda ortaya koydukları kişilik özelliklerinden biri olan "dışa dönük kişilik özelliği" nin, bireylerin içinde bulundukları gruba yönelik uyumları üzerindeki etkisi çalışılmıştır. Bu kapsamda konunun daha iyi anlaşılabilmesi için araştırma evreninde bulunan bireylerin demografik özellikleri ile grup uyumunun bir altında bulunan görev bütünlüğü ile grubun sosyal çekiciliğine yönelik faktörel sinıflandırmalardan faydalanılmış, dışadönük kişilik özelliği ile bu faktörler arasındaki ilişkiler incelenmiştir.

Araştırma içeriğinde öne sürülen hipotezlerin test edilmesi için yapılan analizler sonucunda; araştırma evrenini teşkil eden özel güvenlik personelinin iş tecrübesi (çalışma süresi) arttıkça dişa dönük kişilik özellik düzeylerinin azaldığı saptanmıştır. Bu durum araştırmaya katılan özel güvenlik çalışanlarının iş yeri sosyalleşmeleri ile yakından ilgili olarak değerlendirilebilir. Buna göre elde edilen sonuç literatürdeki benzer çalışmaların kimisiyle örtüşmekte (Brett, 1980; Jackson vd., 1993) kimisiyle de örtüşmemektedir (Lott ve Lott, 1965; Zander, 1979; Wagner vd., 1984). 10 yıldan fazla süre özel güvenlik görevlisi olarak çalışan katılımcıların X kuşağı üyeleri oldukları göz önünde bulundurulursa; diğerlerine kıyasla tedbirli, deneyime, değişime daha kapalı oldukları düşünülebilir. Bu duruma yapılan işin niteliğinin de etkili olduğu varsayılabilir. Zira durağan, rutin ve vardiya şeklinde görev yapan özel güvenlik çalışanları için bu tür bir görevi uzun süre yapmak onların dişa dönük kişilik özelliklerinin de körelmesine sebep olmuş olabilir. Benzer nitelikte görevlerin çalışanlar üzerinde olumsuz sonuçlar oluşturduğu literatürdeki mevcut çalışmalarla da ortaya konulmuştur (Andrade vd., 2017; Schneider ve Harknett, 2019).

Analizler sonucunda öncelikle lise ve üniversite mezunu özel güvenlik personelinin grup sosyal çekicilik algılarının fazla olduğu anlaşılmaktadır. Konuya derinlemesine analiz ile bakıldığında ise üniversite mezunu 
özel güvenlik personelinin grubun sosyal çekiciliği algısının lise mezunlarına göre daha fazla olduğu saptanmıştır. Mevcut literatüre bakıldığında her ne kadar sosyal çekicilik ile ilgili olan çalışmaların varlığını görmek mümkün olsa da (Kiesler, 1963; Wright ve Duncan, 1986; Hogg ve Hardie,1991) bu sonucu destekleyici ya da karşıt bir sonuç ileri süren bir çalışma görülmemektedir. Araştırmada yer alan sosyal çekicilik ile ilgili sorulara bakıldığında 3. bölümde yer alan ve olumsuz anlam ifade eden 2., 3. ve 4. sorulara verilen yanitların da olumsuz olduğu görülmektedir. Olumlu olarak değerlendirilebilecek bu durumda eğitim düzeyleri yüksek olan özel güvenlik personelinin neden grup sosyal çekicilik algısının yüksek olduğu sorusunun cevabının bölgesel eğitim düzeyinin sosyal rol kazandırıp kazandırmamasında yattığı düşünülebilir. Hakkâri ilindeki eğitim düzeyi Türkiye baz alınarak değerlendirildiğinde ortalamanın hayli altında görülmektedir. Buna göre Hakkâri'de ortaokul, lise, yüksekokul, üniversite, yüksek lisans ve doktoradan mezun olan kişi sayısı Türkiye' de bu eğitim düzeyinde olanların 3/1000'ünü oluşturmaktadır (Ulusal Eğitim İstatistikleri Veri Tabanı, 2020). Bu nedenle "eğitimli olma" burada yaşayan insanlar için sosyal gruplaşma veya sosyal bir gruba üye olma açısından önemli olarak görülebilir. Diğer taraftan bölgede yaşanan yoğun terör olayları, güvenlik sağlayanların kim olduklarını da ön plana çıkarmaktadır. Bu kapsamda değerlendirildiğinde güvenlik sağlayan kişilerin bu yörede "güvenilir kişi" olarak değerlendirilmesinin de grup sosyal çekicilik algisı üzerinde etkili olduğu değerlendirilebilir.

Özel güvenlik personelinin grup uyumunun her iki boyutu ile iş tecrübesi değişkeni ortalamaları arasında anlamlı bir farklılık saptanmıştır. Buna göre iş tecrübesi arttıkça grupla görev bütünlüğü değerleri azalırken, grubun sosyal çekiciliği değerleri artış göstermektedir. Çalışanların iş tecrübesi arttıkça görevle bütünleşmesi beklenmektedir. Bu sonucun açıklanmasında araştırmaya dâhil edilmeyen (iş tatmini, örgütsel adalet) başka değişenler etkili olabilir. Diğer taraftan çalışanların iş tecrübesinin artmasıyla birlikte grubun sosyal çekiciliğinin de artması, çalışanların grupta geçirdiği süre artmasıyla grubun sosyal faaliyetlerine katılma oranının da artmasıyla açıklanabilir.

Dışa dönük kişilik özelliğinin grup uyumu üzerinde anlamlı bir etkisi olduğu araştırmanın bir diğer sonucudur. Bu sonuç literatürdeki mevcut araştırma sonuçlarının kimisiyle örtüştügü halde (Barrick, 1998) kimisiyle örtüşmemektedir (Van Vianen ve De Dreu, 2001) Günümüzde örgütlerde kişinin çalıştığı grup ile uyumu da önemli hale gelmiştir. Grup ile olan uyum bireysel, grup ve örgüt düzeyinde olumlu etkileri beraberinde getirmektedir. Bireyler örgütte bulundukları grupla uyum sağladıklarında örgüte bağlanırlar ve örgüt amaçları doğrultusunda çalışmaya daha istekli olurlar. Bu sayede yeteneklerini, fikirlerini daha etkin ve örgüt yararına olacak şekilde aktarabilirler. Bu nedenle işe alım süreçlerinde kişilik değerlendirme testleri kullanarak çalışanların kişilik özellikleri tespit edilebilir ve bu sonuçlara göre çalışan alımını gerçekleştirebilir, örgütte çalışan bireylerin kişilik özellikleri bilinerek, uyum içinde çalışabilecekleri gruplar oluşturulabilir.

$\mathrm{Bu}$ araştırmanın özel güvenlik personeli özelinde gerçekleştirilmesi bir kısıt olarak belirtilebilir. Farklı sektörlerde farklı meslek grupları ile yapılacak araştırmalar ile sonuçların genellenebilirliği genişletilebilir. Ankete katılanların anket sorularını samimi bir şekilde yanıtladıkları ön kabulü araştırmanın bir diğer kisitıdir.

Grup uyumu ile ilgili akademik literatür incelendiğinde söz konusu kavramın genel olarak performans, verimlilik, liderlik gibi kavramlarla karşılıklı olarak değerlendirilip ölçüldüğü anlaşılmaktadır (Dobbins ve Zaccaro, 1986; Greene, 1989; Turner vd. , 1992; Carron ve Brawley, 2000; Evans ve Dion, 2012). Yapilan bu çalışma grubun temeli olan bireyin kişilik özellikleri baz alınarak yapıldığından ancak kendisinden sonraki benzer çalışmalarla uyumlu bir sonuç elde edilip edilmediği anlaşılabilecektir. Bu kapsamda gelecekte grup uyumu ile ilgili olarak yapılacak çalışmalarda grubu bir çoğunluk olarak değerlendirmekten çok grubu oluşturan bireylerin düşünsel ve psikolojik yapıları üzerinde de durulmalıdır.

Son olarak bu çalışma özel güvenlik personeli ile gerçekleştirilmiştir. Farklı meslek üyelerinin grup uyumlarının karşılaştırmalı olarak incelenmesinin literatüre katkı sağlayacağı düşünülmektedir. 


\section{KAYNAKÇA}

Adorno, T. W., Frenkel-Brunswik, E., Levinson, D.J. and Sanford, R. N. (1950). The Authoritarian Personality, New York,Harper \& Brothers.

Ahronson, A. and Cameron, J.E. (2007). The Nature and Consequences of Group Cohesion in a Military Sample. Military Psychology, 19 (1), 9-25.

Allport G.W. and Odbert, H.S. (1936). Trait Names: A Psycho-Lexical Study, USA, Psychological Review Company.

Andrade, N.C.L., Pedrosa, F.G., Lobo, I.L.B. and Bicalho, C.C.F. (2017). The Effects of Work Routine and Professional Satisfaction on Burnout among High-School Teachers, International Journal of Humanities and Social Science Invention, 6 (4), 50-55.

Balch, R.W. (1972). The Police Personality: Fact or Fiction?, The Journal of Criminal Law, Criminology and Police Science, 63 (1), 106-119.

Barrick, M.R., Steward, G.L., Neubert, N.J., and Mount, M.K. (1998). Relating Member Ability and Personality to Work-Team Processes and Team Effectiveness, Journal of Applied Psychology, 83(3), 377-391.

Beauchaine, T. P., Gatzke-Kop, L. M., and Hinshaw, S. P. (2008). Genetic and environmental influences on

Behavior, Beauchaine, T. P. and Hinshaw, S. P., (Eds.), Child and Adolescent Psychopathology, New Jersey, Wiley, 58-90.

Beal, D.J., Cohen, R.R. and McLendon, C.L. (2003). Cohesion and Performance in Groups: A Meta-analytic Clarification of Construct Relations, Journal of Applied Psychology, 88 (6), 989-1004.

Bettenhausen, K.L. (1991). Five Yeras of Groups Research: What We Have Learned and What Needs to Be Addressed, Journal of Management, 17 (2), 345-381.

Billings, P. R., Backwith, J. and Alper, J. S. (1992). The Genetic Analysis of Human Behavior: A New Era? Social Science \& Medicine, 35(3), 227-238.

Brett, J.M. (1980). The Effect of Job Transfer on Employees and Their Families,Cooper, C.L, and Payne, O.,

(Eds.), Current Concerns in Occupational Stress, New York, John Wiley and Sons, 99-136.

Broudy, M.S. (2019). WWII And Its Impact On Psychology, https://www.online-psychologydegrees.org/study/wwii-psychology-impact/, (Erişim Tarihi:31.05.2020)

Clark, J.P. (1965). Isolation of the Police: A Comparison of the British and American Situations, The Journal of

Criminal Law, Criminology and Police Science, 56 (3), 307-319.

Carron, A. V. (1982). Cohesiveness in sport groups: Interpretations and considerations, Journal of Sport Psychology, 4(2), 123-138

Carron, A.V., Widmeyer, W.N. and Brawley, L.R. (1985). The Development of an Instrument to Assess Cohesion in Sport Teams: The Group Environment Questionnaire, Journal of Sport Psychology, 7 (3), 244-266.

Carron, A.V. and Spink, K.S. (1995). The Group Size-Cohesion Relationship in Minimal Groups, Small Group Research, 26 (1), 86-105.

Carron, A.V. and Brawley, L.R. (2000). Cohesion: Conceptual and Measurement Issues, Small Group Research,

31 (1), 89-106.

Carron, A.V., Bray, S.R. and Eys, M.A.(2002). Team Cohesion and Team Success in Sport, Journal of Sports Sciences, 20 (2), 119-126.

Carron, A. V., Colman, M. M., Wheeler, J. and Stevens, D. (2002). Cohesion and Performance in Sport: A meta analysis, Journal of Sport \& Exercise Psychology, 24(2), 168-188. 
Carron, A. V., Burke, S.M. and Prapavessis, H. (2004). Self-Presentation and Group Influence, Journal of Applied Sport Psychology, 16:1, 41-58.

Carless, S.A. and De Paola, C. (2000). The Measurement of Cohesion in Work Units, Small Group Research, 31 (1), 71-88.

Cattell, R. B. (1943). The description of personality: Basic traits resolved into clusters, Journal of Abnormal and Social Psychology, 38, 476-506.

Cattell, R.B. (1957). Personality and Motivation: Structure and Measurement, USA, World Book Company.

Cattell, H.E.P. and Schuerger, J.M. (2003). Essentials of 16PF Assessment, Canada, John Wiley and Sons, Inc.

Charney, E. (2016). Genes, behavior, and behavior genetics, Wiley Interdisciplinary Reviews: Cognitive Science, $8(1-2)$.

Conklin, E.S. (1927). The Determination of Normal Extravert-Introvert Interest Differences, The Pedagogical Seminary and Journal of Genetic Psychology, 34(1), 28-37.

Dion, K.L. (2000). Group Cohesion: From “Field of Forces" to Multidimensional Construct, Group Dynamics, $4(1), 7-26$.

Dobbins, G.H., and Zaccaro, S.J. (1986). The Effects of Group Cohesion and Leader Behavior in Subordinate Satisfaction, Group and Organization Studies, 11 (3), 203-29.

Dumont, F. (2010). A History of Personality Psychology, New York, Cambridge University Press.

Evans, C.R. and Dion K.L. (2012). Group Coesion and Performance: A Meta-Analysis, Small Group Research, 43 (6), 690-701.

Festinger, L., Schachter, S. and Back, K. (1950a). Social Pressures in Informal Groups, California, Stanford University Press.

Festinger, L. (1950b). Informal Social Communication, Psychological Review, 57 (5), 271-282.

Fine, G.A. and Holyfield, L. (1996). Secrecy, Trust, and Dangerous Leisure: Generating Group Cohesion in Voluntary Organizations, Social Psychology Quarterly, 59 (1), 22-28.

Fiorillo, S.(2019). Great Depression: Causes, Effects and Timeline, https://www.thestreet.com/politics/greatdepression-causes-14663720 (Erişim Tarihi: 31.05.2020)

Forsyth, D.R. (1983). An Introduction to Group Dynamics, California, Brooks/Cole Publishing Company.

Goldberg, L.R. (1990). An Alternative Description of Personality: The Big Five Factor Structure, Journal Of Personality and Social Psychology, 59(6), 1216-1229.

Goyal, N. (2010). Industrial Psychology, India,Krishna Prakashan Media (P) Ltd.

Greene, C.N. (1989). Cohesion and Productivity in Work Groups. Small Group Research, 20 (1), 70-86.

Griffith, J. (1988). Measurement of Group Cohesion in U. S. Army Units, Basic and Applied Social Psychology, 9 (2), 149-171.

Gross, N. and Martin W.E. (1952). On Group Cohesiveness, American Journal of Sociology, 57 (6), $546-564$.

Gully, S.M., Devine, D.J. and Whitney, D.J. (2012). A Meta-Analysis of Cohesion and Performance: Effects of Level of Analysis and Task Interdependence, Small Group Research, 43 (6), 702-725.

Gürbüz, S. ve Şahin, F. (2015). Sosyal Bilimlerde Araştırma Yöntemleri, Ankara, Seçkin Yayıncılık.

Hogg, M.A. and Hardie, E.A. (1991). Social Attraction, Personal Attraction, and Self-Categorization: A Field Study, Personality and Social Psychology Bulletin, 17 (2), 175-180.

Hogg, M.A. and Hardie, E.A. (1992). Prototypicality, Conformity and Depersonalized Attraction: A Selfcategorization Analysis of Group Cohesiveness, British Journal of Social Psychology, 31, 41-56. 
Hogg, M.A. (1993). Group Cohesivenes: A Critical Review and Some New Directions, European Review of Social Psychology, 4, 85-111.

Horne, C (201). The Enforcements of Norms: Group Cohesion and Meta-Norms, Social Psychology Quarterly, $64(3), 253-266$.

Jackson, S.E., Stone, V.K. and Alvarez, E.B.(1993). Socialization Amidst Diversity: The Impact of Demographics on Work Team Oldtimers and Newcomers, Research in Organisational Behavior, 15, 45109.

John, O.P. and Srivastava, S. (1999). The Big Five Trait Taxonomy: History, Measurement and Perspectives,

Lawrence, A. P., and Oliver, P. J., (Eds.), Handbook of Personality: Theory and Research, New York, The Guilford Press ,102-138.

Jung, C. G. (1926). The Psychological Types, (Çeviren: H.Godwin Baynes), Great Britain, Edinburg Press.

Kiesler, C.A. (1963). Attraction to the group and conformity to group norms, Journal of Peronality, 31, 559-569.

Lewin, K. (1935). A Dynamic Theory of Personality, New York, McGraw-Hill Book Company.

Lewin, K. (1939). Field Theory and Experiment in Social Psychology: Concepts and Methods, American Journal of Sociology, 44(6), 868-896.

Lott, K.L. (1961). Group Cohesiveness: A Learning Phenomenon, The Journal of Social Psychology, 55, $275-286$.

Lott, A.J. and Lott, B.E. (1965). Group Cohesiveness as Interpersonal Attraction: A Review of Relationships With Antecedent and Consequent Variables, Psychological Bulletin, 64 (4), 259-309

Marrow, A.J. (1969). The Practical Theorist: The Life and Work of Kurt Lewin, USA, Basic Books, Inc., Publishers.

Mayo, E. (1945). The Social Poblems of An Industrial Civilization, Boston, Harvard University Press.

McCrae, R.R. and Costa, P.T., (2004). A contemplated revision of the NEO Five-Factor Inventory, Personality and Individual Differences, 36, 587-596.

McDougall, W. (1933). The Energies of Men, Great Britain, Methuen \& Co. Ltd.

Moreno, J.L. and Jennings H.H. (1938). Statistics of Social Configurations, Sociometry, 1(3/4), 342-374.

Mudrack, P.E. (1989). Defining Group Cohesiveness: A Legacy of Confusion? Small Group Behavior, 20(1), 3749.

Mullen, B. and Copper, C. (1994). The Relation Between Group Cohesiveness and Performance, An Integration Psychological Bulletin, 115 (2), 210-227.

Niederhoffer, A. (1967). Behind the Shield. Garden City.Anchor Books.

Organ, D.W. and Bateman, T. (1986). Organizational Behavior, Texas,Business Publications, Inc.

Plomin, R., Owen, M. J., and McGuffin, P. (1994). The Genetic Basis of Complex Human Behaviors, Science, 264(5166),1733-1739.

Roseborough, M.A. (1953). Experimental Studies of Small Groups, Psychological Bulletin, 50(4), $275-303$.

Rosenman, R.H. (1978). The Role of the Type A Behavior Pattern in Ischaemic Heart Disease: Modification of Its Effects By Beta-blocking Agents, British Journal of Clinical Practice, 32 (1), 58-65.

Schneider, D. and Harknett, K. (2019). Consequences of Routine Work-Schedule Instability for Worker Health and Well-Being, American Sociological Review, 84(1), 82-114

Severt, J.B. and Estrada, A.X. (2015). On the Function of Group Cohesion, Team Cohesion: Advances in Psychological Theory, Methods and Practice, 17, 3-24.

Shephard, B. (2015). Psychology and the Great War, 1914-1918, The Psychologist,28(11), 944-946.

Singh, A.K. (2019). Social Psychology, Delhi, Asoke K. Ghosh, PHI Learning Private Limited. 
Skolnick, J.H (2010). A Sketch of the Policeman's Working Personality, K. R, Stephen, and D. W., Michael (Eds.), Race, Ethnicity, and Policing: New and Essential Readings, USA. New York Uniersity Press, 15-31.

Stokes, J.P. (1983). Components of Group Cohesion: Intermember Attraction, Instrumental Value, and Risk Taking, Small Group Behavior, 14 (2), 163-173.

Şimşek, S. (2015). Polislik Kurumunun İnşası ve Polislerin Meslek Örgütlenmesi: Türkiye, İngiltere Ve Fransa Örnekleri, (Yayınlanmamış Doktora Tezi), Ankara, Türkiye ve Ortadoğu Amme İdaresi Enstitüsü (TODAİE).

Turner, M., Pratkanis, A.R., Probasco, P. and Leve, C. (1992). Threat, Cohesion, and Group Effectiveness: Testing a Social, Journal of Personality and Social Psychology, 63 (5), 781-796.

Tziner, A. (1982). Differenial Effects of Group Cohesiveness Types: A Clarifying Overview, Social Behavior and Personality, 10 (2), 227-240.

Ulusal Eğitim İstatistikleri Veri Tabanı, https://biruni.tuik.gov.tr/medas/?kn=130\&locale=tr, (Erişim tarihi: 23.08.2020)

Van Bergen, A. and Koekebakker, J. (1959). "Group Cohesiveness" in Laboratory Experiments, Acta Psychologica, 16, 81-98.

Van Vianen, A.E.M. and De Dreu, C.K.W. (2001) Personality in teams: Its relationship to social cohesion, task cohesion, and team performance, European Journal of Work and Organizational Psychology, 10(2), 97-120.

Wagner, G.W, Pfeffer, J. and O'Reilly, C.A. (1984). “Organizational Demography and Turnover in TopManagement Group", Administrative Science Quarterly, 29 (1), 74-92.

Wright, T. L. and Duncan, D. (1986). Attraction To Group, Group Cohesiveness, and Individual Outcome. Small Group Behavior, 17(4), 487-492.

Zander, A. (1979). Psychology of the Group Processes, Annual Review of Psychology, 30, 417-451. 